\title{
PENGARUH PENGUASAAN TANDA BACA TERHADAP KETERAMPILAN MENULIS KARANGAN DESKREPSI SISWA \\ KELAS VIII SMP NEGERI 7 LAWE SIGALA-GALA KECAMATAN BABUL MAKMUR KUTA CANE ACEH TENGGARA
}

\author{
Muhammad Supratman / NIDN. 1331039001 \\ STKIP US KUTACANE \\ Email : muhammad.supratman90@gmail.com
}

\begin{abstract}
Abstrak
Keterampilan berbahasa pada hakekatnya mencakup 4 aspek, yaitu menyimak, berbicara, membaca, dan menulis. Pengembangan salah satu aspek keterampilan berbahasa itu harus didukung oleh ketiga aspek lainnya, karena keempat aspek keterampilan berbahasa itu merupakan satu kesatuan. Tanpa dukungan itu mustahil satu aspek dapat berkembang dengan sendirinya. Menulis sebagai salah satu aspek keterampilan bahasa tidak berdiri sendiri sebagai salah satu aspek keterampilan bahasa tetapi, mencakup pula beberapa unsur didalamnya. Salah satu unsur diantaranya ialah tanda baca. Dengan demikian tanda baca dalam proses belajar mengajar bahasa Indonesia, harus dapat perhatian guru bidang study bahasa indonesia. Rumusan masalah dalam penelitian ini adalah "apakah ada pengaruh antara penguasaan tanda baca terhadap keterampilan menulis deskripsi siswa kelas VIII Negeri 7 Lawe Sigala-gala Kecamatan Babul Makmur Kuta Cane Aceh Tenggara. Populasi penelitian adalah seluruh siswa kelas VIII Negeri 7 Lawe Sigala-gala Kecamatan Babul Makmur Kuta Cane Aceh Tenggara, yang berjumlah 120 orang terdiri 3 kelas. Karena jumlah populasi begitu besar, maka jumlah populasi sebagaian dijadikan secara acak yaitu sebanyak 50 orang (sampling random).
\end{abstract}

Kata kunci : tanda baca, menulis, karangan deskripsi

PENDAHULUAN

Perasaan seseorang harus
mempunyai kemampuan bahasa,
baik secara lisan maupun tulisan.

Bahasa sebagai alat

komunikasi memegang peranan

penting dalam kehidupan manusia

dalam bermasyarakat. Hal ini dapat

dirasakan dalm tindakan-tindakan

sosial untuk saling mengemukakan

pendapat,ide,gagasan,informasi,dan

\begin{abstract}
Sehubungan dengan ini Ambary mengemukakan pendapatnya, "Bahasa adalah lembaga bunyi suara yang dihasilkan oleh alat ucap manusia sebagai alat
\end{abstract}


komunikasi antra anggota dalam menyampaikan masyarakat (Ambary, 1989:6).

Menurut kurikulum bahasa indonesia 1987, pengajaran bahasa indonesia meliputi aspek keterampilan menyimak, berbicara, membaca, dan menulis. Masing-masing aspek tersebut mencakup beberapa unsurdi dalamnya. Berdasarkan pada kurikulum bahasa indonesia, jelaskan bahwa menulis merupakan salah satuaspek kemampuan berbahasa yang juga harus mendapat perhatian guru dalam pengajaran.

Menulis sebagai salah satu aspek keterampilan berbahasa tidak berdiri sendiri, tetapi, mencakup pula beberapa unsur di dalamnya. Salah satu unsur diantaranya ialah tanda baca. Dengan demikian tanda baca dalam proses belajar mengajar bahasa indonesia, harus mendapat perhatian guru bidang studi bahasa indonesia.

Oleh karena itu siswa SMP Negeri 7 Lawe Sigala-gala Kecamatan Babul Makmur Kuta Cane Aceh Tenggara dituntut memiliki pengetahuan tanda baca yang benar, sebab tanpa pengetahuan tanda baca yang benar, seswa akan mendapat kesulitan 
keraf mengatakan,'Tanda baca yang lazim digunakan dewasa ini didasarkan atas nada dan lagu (Suprasegmental) dan sebagian direlasikan atas dramatikal”.

Secara singkat tanda baca adalah tanda-tanda atau sesutu yang dipakai dalam bahasa tulis yang merupakan konvensional didasarkan atas nada dan lagu(suprasegmental) dan sebagai besar direlasikan atas gramatikal. Diantara aturan-aturan yang diperlukan ialah tanda baca. Dalam buku ejaan bahasa indonesia yang disempurnakan, tanda baca terdiri dari :

$\begin{array}{lll}\text { 1. } & \text { Tanda titik } & (\text {. }) \\ \text { 2. } & \text { Tanda koma } & (,) \\ \text { 3. } & \text { Tanda titik koma } & (\text {; ) } \\ \text { 4. } & \text { Tanda titik dua } & (\text { : }) \\ \text { 5. } & \text { Tanda hubung } & (-) \\ \text { 6. } & \text { Tanda petik } & \end{array}$<smiles>[CH][CH]</smiles>

7. Tanda petik ( “........”)

8. Tanda garis miring (/)

9. Ellipsis (...)

10. Tanda seru

Dalam kamus umumbahasa indonesia dapat menemukan pengertian menulis sebagai berikut:"Menulis adalah melahirkan pemikiran atau perasaan (seperti mengarang, membuat surat dan sebagainya) dengan tulisan”.(poerwadarminta, 1985:1098).pendapt ini begitu sederhanayaitu setiap tulisan yang merupakan curahanhati dapat dikatakan menulis, jadi dari pendapat ini pengertian dari tulisan itu sendiri tidak dijelaskan secara rinci.

Selanjutnya $\begin{array}{r}\text { M.Silitonga } \\ \text { dalam tulisannya menyimpulkan }\end{array}$
bahwa,"menulis adalah tulis sebagai
alatnya".(Silitonga,1987:11).

H.G. Tarigan berpendapat bahwa, "Tulisan deskripisi adalah tulisan yang berusaha melukiskan atau memberikan suatu objek beserta rinciannya."(Tarigan,1982:89).

Tujuan utama penulis deskripsi ialah agar pembaca seolah-olah dapat melihat, mencium, dan merasakan apa yang dilihat, didengar, dan dirasakan.

Contoh :

Jauh disana terhampar rumput hijau. Pada tempat lalang berbunga putih beralun-alun sambil berayun-ayun dengan rumput yang dihembus udara petang. Dibawah 
lingkungan pembatas bumi dan langit, segaris hijau kebiru-biruan. Dari balik garis hijau kebiruan naik memancar warna merah menyala yang makin keatas hilang melayang warnanya. Jauh sedikit dari sana, tumpukan awan berbagai bentuk yang terkadang lekas berubah rupa, diembus anginan kesenjaan menyapu halus puspa warna.

Berdasarkan latar belakang
maka rumusan masalah yang di
kemukakan dalam $\begin{array}{r}\text { penelitian } \\ \text { pengaruh }\end{array}$
adalah:bagaimanakah penguasaan tanda baca
terhadap keterampilan menulis
deskripsi siswa kelas VII SMP
Negeri 7 Lawe Sigala-gala
Kecamatan Babul Makmur Kota
Cane Aceh Tenggara.

\section{METODE PENELITIAN}

Penelitian ini merupakan
penelitian deskripsi korelasional
bertujuan melihat hubungan atau
pengaruh antara dua gejala atau
lebih. Secara singkat dan sederhana
dapat dikatakan bahwa populasi dan
sampel merupakan sumber
data.Sunjana,(1984:57) mengatakan

bahwa "populasi adalah totalitas semua kuantitatif ataupun kualitatif dari pada karakteristik tertentu mengenai sekumpulan obyek yang lengkap dan jelas".

Jadi pada dasarnya populasi adalah keseluruhan obyek yang akan diamati atau menjadi sasaran penelitian. Dalam penelitian ini yang menjadi populasi adalah siswa kelas VIII SMP Negeri 7 Lawe Sigal-gala Kecamatan Babul Makmur Kuta Cane Aceh Tenggara.

Selanjutnya Trisno Hadi (1987:75) mengatakan : "dari jumlah populasi diambil sebagai objek yang dapat yang mewakili populasi, inilah yang disebut sampel. Sementara itu ampling adalah cara yang digunakan untuk mengambil sampel”.

Dalam penelitian ini penulis mengambil sampel berdasarkan pandapat Arikunto (1984:104)yang mengatakan :'Untuk sekedar ancerancer, maka apabila subjeknya kurang dari 100, lebih baik diambil semuanya sehingga penelitiannya merupakan penelitian populasi selanjutnya jika subyek lebih dari 100 dapat diambil $10-15 \%$ atau 20 $25 \%$ atau lebih".

Vol.3 No. 2 Juli- Desember 2018/ 177 
Berdasarkan pendapat diatas maka yang menjadi sampel dalam penelitian ini adalah sebagian dari anggota populasi yang diambil secara acak (sampling randam). Jumlah populasi dan sanpel dapat dilihat sebagai berikut:

\begin{tabular}{|c|c|c|c|}
\hline No. & Kelas & Populasi & Sample \\
\hline 1 & VIIIa & 37 & 15 \\
\hline 2 & VIIIb & 42 & 15 \\
\hline 3 & VIIIc & 41 & 20 \\
\hline \multicolumn{2}{|c|}{ Total } & 120 & 50 \\
\hline
\end{tabular}

\section{HASIL DAN PEMBAHASAN}

$$
\text { Untuk membuktikan }
$$

hipotesis penelitian ini akan digunakan data-data. Data-data tersebut adalah hasil wawancara yang ditujukan kepada guru, hasil tes yang disebarkan kepada siswa yaitu:

a) Tes penguasaan tanda baca

b) Tes kemampuan menulis deskripsiyang dikerjakan siswa

Setelah data-data diperoleh dan dikumpulkan, maka langkah selanjutnya melakukan pengolahan dan analisis terhadap data-data tersebut, yang nantinya akan digunakan untuk melakukan pengujian hipotesis sesuai dengan kriteria pengujian hipotesis yang telah dijelaskan di atas.

Untuk lebih jelasnya pengolahan data tersebut diuraikan sebagai berikut:

1. Wawancara dengan guru Wawancara dilakukan hanya kepada guru bahasa indonesia yang mengajar di kelas VIII. Dalam pelaksanaan wawancara penulis tidak mengalami kesulitan, sebab guru yang mengajar dikelas VIII hanya satu orang. Dengan demikian ia lebih menguasai dan mengetahui perkembangan siswa kelas VIII. Selain itu data yang dibutuhkan akan lebih mudah diperoleh.

Sebelum wawancara diadakan penulis telah mempersiapkan berbagai hal untuk mempelancar pelaksanaan wawancara diantaranya adalah lembaran soal, kertas kosong untuk menulis jawaban dan alat-alat 


$$
\begin{aligned}
& \text { tulis lainnya. Pelaksanaan } \\
& \text { wawancara dilakukan di } \\
& \text { ruang guru. } \\
& \text { Setelah diadakan wawancara } \\
& \text { penulis menyebarkan angket } \\
& \text { kepada siswa yang berupa tes } \\
& \text { penguasaan tanda baca dan } \\
& \text { tes kemampuan menulis } \\
& \text { deskripsi yang dikerjakan } \\
& \text { siswa. Setelah data-data } \\
& \text { diperoleh dan dikumpulkan, } \\
& \text { maka langkah selanjutnya } \\
& \text { melakukan pengolahan dan } \\
& \text { analisis terhadap data-data } \\
& \text { tersebut, yang nantinya akan } \\
& \text { digunakan untuk melakukan } \\
& \text { pengujian hipotesis sesuai } \\
& \text { dengan kriteria pengujian } \\
& \text { hipotesis yang telah } \\
& \text { dijelaskan di atas. }
\end{aligned}
$$

Untuk lebih jelasnya pengolahan data tersebut diuraikan sebagai berikut:

2. Wawancara dengan guru

Wawancara dilakukan hanya kepada guru bahasa indonesia yang mengajar di kelas VIII. Dalam pelaksanaan wawancara penulis tidak mengalami kesulitan, sebab guru yang mengajar dikelas
VIII hanya satu orang. Dengan demikian ia lebih menguasai dan mengetahui perkembangan siswa kelas VIII. Selain itu data yang dibutuhkan akan lebih mudah diperoleh.

Sebelum wawancara diadakan penulis telah mempersiapkan berbagai hal untuk mempelancar pelaksanaan wawancara diantaranya adalah lembaran soal, kertas kosong untuk menulis jawaban dan alat-alat tulis lainnya. Pelaksanaan wawancara dilakukan di ruang guru.

Setelah diadakan wawancara penulis menyebarkan angket kepada siswa yang berupa tes penguasaan tanda baca dan tes kemampuan menulis deskripsi yang dikerjakan siswa.

Berdasarkan keterangan dan data yang penulis kumpulkan, maka dapat ditarik kesimpulan sebagai berikut:

1. Bahasa adalah alat manusia untuk 
menyampaikan,perasaannya,piki

rannya,dan kehendaknya dengan memakai alat binyi.

2. Menulis adalah melahirkan pikiran atau perasaan melalui tulisan sebagai mediannya,sehingga orang lain akan dapat memahaminya.

3. Pengguna tanda baca dalam menulis sangat penting, karena menggambarkan pengetahuan dalam mengungkapkan perasaan,pikiran,dan

kehendaknya.

4. Seseorang akan terampil menulis dengan adanya bakat yang dimiliki dan latihan yang berkesinambungan,

5. Tujuan pengajaran menulis, membekali siswa supaya dapat mengembangkan idea tau pikiranya untuk menulis dan menjadikan siswa berpikir kritis serta berguna untuk melanjutkan studi dan bekal untuk terjun ditengah-tengah masyarakat.

6. Pengembangan aspek keterampilan menulis dalam pengajaran di sekolah, harus dikaitkan dengan ketiga keterampilan berbahasa lainnya.

\section{DAFTAR PUSTAKA}

Ambary, Abdullah. 1987. Inti Sari Tatabahasa Indonesia, Bandung : Jinika

Arikunto, Suharsimi. 1984. DasarDasat Kependidikan. Jakarta : Bina Aksara

Hadi, Sutrisno. 1987. Metodolologi Research, Yogyakarta : Andi Offset.

Mojowasito, S. 1982. Kamus Lengkap Bahasa IndonesiaMasa Kini. Surabaya :Terbit Terang.

Poerwardaminta, W.J.S. 1985. Kamus Umum Bahasa Indonesia. Jakarta : Balai Pustaka.

Silitonga, M. 1987.Kemampuan Bahasa Indonesia (Membaca dan Menulis), Medan : FKSS IKIP

Sudjana, 1984. Metode Research, Bandung : Tarsi.

Tarigan, Henri Guntur. 1986. Menulis Suatu Keterampilan Berbahasa. Bandung : Angkasa. 